\title{
IbM PEMANFATAN TEKNOLOGI TEPAT GUNA PEMBUATAN BRIKET LIMBAH KOTORAN TERNAK RUMINANSIA
}

\author{
Asmaul Khusna ${ }^{1}$, Ninik Sri Rahayu ${ }^{2}$, Sari Wiji Utami ${ }^{3}$, Nuraini Lusi ${ }^{4}$ \\ Program Studi Teknologi Pengolahan Hasil Ternak, Politeknik Negeri Banyuwangi \\ Jl. Raya Jember Km. 13, Labanasem, Kabat, Banyuwangi \\ ${ }^{1}$ Akhusna@poliwangi.ac.id \\ ${ }^{2}$ ninikrahayu375@gmail.com \\ ${ }^{3}$ sariwijiutami@gmail.com \\ ${ }^{4}$ nurainilusi@gmail.com
}

\begin{abstract}
Desa Kumendung terletak di kecamatan Muncar, Kabupaten Banyuwangi, mempunyai luas sebesar $5,37 \mathrm{~km}^{2}$, dengan jumlah penduduk sebanyak 6.135 jiwa. Mata pencaharian utama penduduknya adalah sebagai nelayan, petani, dan peternak. Sub sektor peternakan mempunyai peran yang sangat penting bagi kehidupan masyarakat desa Kumendung.

Jumlah ternak yang cukup banyak di desa Kumendung memberikan dampak terhadap pencemaran lingkungan. Kotoran ternak ruminansia yang ada belum diolah menjadi pupuk organik maupun sumber energi yang dapat dimanfaatkan oleh warga. Kotoran ternak ruminansia yang tidak dikelola dengan baik dapat menurunkan kualitas lingkungan. Gas methana $\left(\mathrm{CH}_{4}\right)$ yang dihasilkan oleh kotoran sapi merupakan penyumbang terbesar pada efek rumah kaca.

Masyarakat desa Kumendung saat ini masih banyak yang menggunakan kayu sebagai bahan bakar. Penggunaan kayu sebagai bahan bakar dapat digantikan dengan briket yang berbahan baku dari kotoran ternak ruminansia. Briket kotoran ternak ruminansia sebagai bahan bakar pengganti kayu bakar dapat menurunkan dampak lingkungan yang diakibatkan oleh limbah kotoran ternak dan dapat mengurangi penebangan pohon. Selain itu, briket mempunyai keuntungan ekonomis karena dapat diproduksi secara sederhana, memiliki nilai kalor yang tinggi, dan ketersediaan bahan bakunya melimpah di Indonesia sehingga dapat bersaing dengan bahan bakar lain.

Pemanfaatan teknologi tepat guna yang akan dilakukan melalui kegiatan pengabdian masyarakat ini diharapkan dapat membantu mitra sasaran dalam memanfaatkan, mengolah, serta menambah added value limbah ternak ruminansia, sehingga perekonomian masyarakat juga dapat ikut terangkat. Selain bekerja dengan mata pencaharian utamanya, masyarakat desa Kumendung juga dapat mendapatkan penghasilan tambahan, atau setidaknya menekan pengeluaran untuk membeli bahan bakar berupa kayu maupun gas elpiji.
\end{abstract}

Kata Kunci: Added value, briket, limbah ternak ruminansia, teknologi tepat guna

\section{PENDAHULUAN}

Desa Kumendung adalah salah satu desa yang berada di kecamatan Muncar kabupaten Banyuwangi, mempunyai luas sebesar $5,37 \mathrm{~km}^{2}$, dengan jumlah penduduk sebanyak 6.135 jiwa. Mata pencaharian utama penduduknya adalah sebagai nelayan, petani, dan peternak. Sub sektor peternakan mempunyai peran yang sangat penting bagi kehidupan masyarakat desa
Kumendung dengan jumlah ternak sapi potong sebanyak 6.447 ekor, kerbau sebanyak 42 ekor, kambing sebanyak 7.674 ekor dan domba sebanyak 3.492 ekor (Dinas Peternakan Banyuwangi, 2016).

Jumlah ternak yang cukup banyak di desa Kumendung memberikan dampak terhadap pencemaran lingkungan. Kotoran ternak ruminansia yang ada belum diolah menjadi 
pupuk organik maupun sumber energi yang dapat dimanfaatkan oleh warga. Kotoran ternak ruminansia yang tidak dikelola dengan baik dapat menurunkan kualitas lingkungan. Gas Methana $\left(\mathrm{CH}_{4}\right)$ yang dihasilkan oleh kotoran sapi merupakan penyumbang terbesar pada efek rumah kaca (Putri et al., 2014). Kotoran ternak ruminansia dapat dimanfaatkan menjadi briket. Briket mempunyai keuntungan ekonomis karena dapat diproduksi secara sederhana, memiliki nilai kalor yang tinggi, dan ketersediaan bahan bakunya melimpah di Indonesia sehingga dapat bersaing dengan bahan bakar lain (Santoso et al., 2010).

Masyarakat desa Kumendung saat ini masih banyak yang menggunakan kayu sebagai bahan bakar. Penggunaan kayu sebagai bahan bakar dapat digantikan dengan briket yang berbahan baku dari kotoran ternak ruminansia. Briket kotoran ternak ruminansia sebagai bahan bakar pengganti kayu bakar dapat menurunkan dampak lingkungan yang diakibatkan oleh limbah kotoran ternak dan dapat mengurangi penebangan pohon.

\section{TARGET DAN LUARAN}

Limbah ternak ruminansia mempunyai sumbangan yang cukup tinggi terhadap pencemaran lingkungan, termasuk pembuangan pada tanah dan air permukaan, serta emisi ke atmosfer (Kasworo et al., 2013). Seekor sapi dengan bobot badan $454 \mathrm{~kg}$ akan menghasilkan $30 \mathrm{~kg}$ limbah feses dan urin setiap hari, jika di desa Kumendung terdapat 6.447 ekor sapi maka akan menghasilkan feses dan urin sebanyak 193,41 ton. Kotoran ternak ruminasia tersebut sangat potensial apabila diolah menjadi biomassa agar tidak mencemari lingkungan. Masyarakat mitra IbM harus mendapatkan pelatihan dalam penanganan limbah kotoran ternak ruminansia, mengingat jumlah ternak ruminansia yang cukup banyak di desa Kumendung. Penanganan limbah yang disarankan adalah mengolah limbah menjadi bahan bakar briket. Pemanfaatan limbah kotoran ternak ruminasia menjadi briket sebagai bahan bakar lebih efisien dan mudah untuk dipraktekkan dibandingkan dengan pemanfaatan limbah kotoran ternak ruminansia menjadi biogas.

Tabel 1. Rencana Target dan Luaran

\begin{tabular}{llrl}
\hline No & \multicolumn{1}{c}{ Hasil luaran } & \multicolumn{1}{c}{ indikator } \\
\hline 1 & $\begin{array}{l}\text { Publikasi Ilmiar } \\
\text { jurnal/prosiding }\end{array}$ & di & Submitted \\
2 & $\begin{array}{l}\text { Publikasi pada media masa } \\
\text { (cetak/ elektronik) }\end{array}$ & Tidak ada \\
3 & $\begin{array}{l}\text { Peningkatan omzet pada mitra } \\
\text { yang bergerak dalam bidang } \\
\text { ekonomi Tidak ada }\end{array}$ & \\
4 & $\begin{array}{l}\text { Peningkatan kualitas dan } \\
\text { kuantitas produk }\end{array}$ & Tidak ada \\
5 & $\begin{array}{l}\text { Peningkatan pemahaman dan } \\
\text { Ada }\end{array}$ \\
\hline
\end{tabular}

\begin{tabular}{lll}
\hline & ketrampilan masyarakat \\
6 & $\begin{array}{l}\text { Peningkatan ketrampilan } \\
\text { kesehatan masyarakat } \\
\text { Jasa, model, rekayasa, sistem, } \\
\text { produk/barang }\end{array}$ & Pda \\
7 & Hak kekayaan intelektual \\
8 & Buku ajar & Tidak ada \\
9 & Tidak ada \\
\hline
\end{tabular}

Sumber: Hasil Analisis (2016)

\section{METODE PELAKSANAAN}

Kegiatan pengabdian ini akan dilakukan dalam beberapa tahapan dan alur pelaksanaan yang meliputi:

1. Survey sarana (lokasi) pengabdian

Melakukan survey untuk mengidentifikasi lokasi yang perlu dilakukan pengabdian dengan datang langsung ke daerah/desa yang dijadikan objek pengabdian, yaitu desa

Kumendung, kecamatan Muncar.

2. Mempersiapkan sarana dan Prasarana

a. Mempersiapkan laboratorium/workshop untuk kegiatan pelatihan pembuatan briket kotoran ternak ruminansia.

b. Melakukan persiapan alat pencetak briket dan bahan yang digunakan.

c. Persiapan tenaga teknis untuk mengawasi jalannya mesin dan menyiapkan alat-alat yang dibutuhkan dalam pelatihan pembuatan briket kotoran ternak.

d. Pada tahap persiapan sarana dan prasarana mesin pembuat briket sudah siap untuk digunakan.

3. Rekruitmen peserta pelatihan

Mendata warga daerah studi yang memiliki ternak ruminansia melalui kepala desa Kumendung dan diambil peserta sebanyak 25 orang. Pada tahap rekruitmen peserta pelatihan akan dilaksanakan setelah pengajuan proposal ini disetujui.

4. Kegiatan pelatihan

Kegiatan pelatihan ini berlangsung selama dua (2) hari di Balai Desa. Pertama peserta akan mendapat pemaparan tentang bahaya lingkungan yang diakibatkan oleh kotoran ternak, kemudian peserta akan mendapatkan pemaparan tentang tata cara pembuatan briket kotoran ternak ruminansia. Hari kedua peserta akan praktek langsung membuat briket kotoran ternak ruminansia dengan menggunakan alat pencetak yang telah disiapkan oleh panitia.

\section{Hasil dan Luaran}

Hasil dan luaran dalam kegiatan IbM ini menyangkut hasil yang diperoleh dalam kegiatan pelatihan tersebut, secara rinci akan dijelaskan sebagai berikut:
a) Modul pelatihan dan sertifikat.
b) Pengetahuan tata cara pembuatan briket kotoran ternak.
c) Dihasilkan briket kotoran ternak ruminansia sebagai bahan bakar. 


\section{HASIL DAN PEMBAHASAN}

Pelaksanaan kegiatan IbM ini, melalui beberapa tahapan yang telah dilakukan oleh tim pelaksana adalah peninjauan ke lokasi mitra yaitu di Desa Kumendung Kecamatan Muncar Kabupaten Banyuwangi. Kegiatan ini dilakukan untuk menggali informasi kebutuhan mitra sehubungan dengan permasalahan yang dihadapi oleh mitra yaitu tentang penanganan kotoran ternak ruminansia yang belum dimanfaatkan dan baunya dapat mencemari lingkungan. Dari pengamatan ini dapat dicapai kesepakatan penyelesaian masalah yang terjadi yaitu pemanfaatan kotoran ternak ruminansia menjadi briket.

Koordinasi dengan tim pelaksana juga dilakukan untuk mendiskusikan tentang perancangan mesin pencetak briket yang sesuai dengan kebutuhan mitra. Diskusi ini mencakup desain alat, bahan-bahan yang dibutuhkan, pembuatan alat, waktu yang dibutuhkan, bengkel teknik yang digunakan untuk pengerjaan alat, serta prediksi waktu pengerjaan.

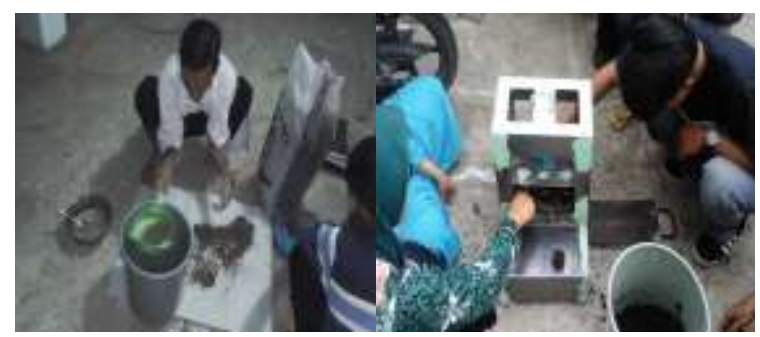

(a)

(b)

Gambar I : (a) Pembuatan adonan briket (b) Pembuatan alat pencetak briket

Setelah mesin pencetak briket siap digunakan, tim pelaksana melakukan sosialisasi dan pelatihan pembuatan briket dengan bahan baku kotoran ternak ruminansia. Kegiatan ini dilaksanakan di Balai Desa Kumendung dengan dihadiri 23 peternak sapi dan kambing. Setelah pelatihan mesin pencetak briket diserahkan kepada kepala Desa Kumendung untuk digunakan oleh peternak yang berminant memproduksi briket kotoran ternak ruminansia.

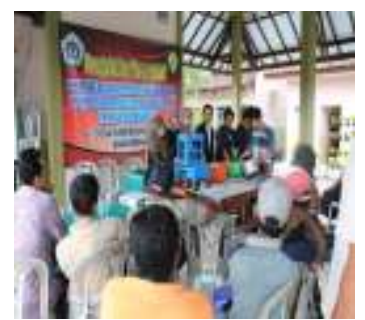

(a)

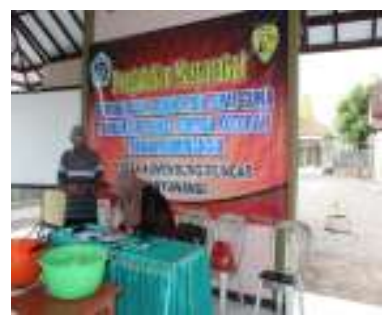

(b)
Gambar II : (a) Pelatihan pembuatan briket

(b) Serah terima alat pencetak briket
Pelaksanaan kegiatan Pengabdian Kepada Masyarakat Program Iptek bagi Masyarakat dengan judul “ IbM Pemanfaatan Teknologi Tepat Guna Pembuatan Briket dari Limbah Kotoran Ternak Ruminansia" di Desa Kumendung Kecamatan Muncar Kabupaten Banyuwangi ini didapatkan hasil yang cukup baik, yaitu sebagai berikut:

1. Melalui kegiatan ini telah dihasilkan satu buah alat pencetak briket hasil perancangan dan pembuatan, yang mempunyai kemampuan untuk mencetak enam briket sekaligus. Bahan baku yang digunakan adalah kotoran sapi yang telah dikeringkan, kemudian dihaluskan dan disaring dengan ukuran 50 mesh, kotoran sapi halus dicampur dengan arang sekam dengan perbandingan $1: 1$. sebagai bahan perekat digunakan tepung kanji yang telah dicampur air sehingga berbentuk seperti lem. Tepung kanji dicampurkan ke dalam adonan kotoran sapi dan arang sekam hingga homogen dan dapat dikepal. Kemudian adonan dimasukkan kedalam alat cetakan hingga penuh kemudian dipres hingga padat. Briket yang dihasilkan berbentuk silinder dengan diameter $30 \mathrm{~mm}$ dan panjang $50 \mathrm{~mm}$. Kemudian briket dijemur dibawah panas matahari hingga benar-benar kering atau dapat dioven dengan suhu $60^{\circ} \mathrm{C}$ selama 24 jam.briket yang sudah kering siap untuk digunakan.

2. Peternak di Desa Kumendung dapat mengaplikasikan teknologi pembuatan briket kotoran sapi ini untuk mengurangi pencemaran lingkungan yang diakibatkan oleh adanya kotoran sapi. Kotoran sapi yang ada selama ini tidak diolah sehingga menimbulkan bau yang kurang sedap.

3. Masyarakat Desa Kumendung dapat menghemat pengeluaran untuk membeli bahan bakar untuk memasak dan dapat beralih ke briket kotoran sapi dengan memanfaatkan kotoran yang dihasilkan oleh ternaknya..

4. Masyarakat Desa Kumendung dapat meningkatkan pendapatan dengan mengolah kotoran sapi menjadi briket. Sebelum adanya kegiatan ini kotoran sapi tidak dapat dimanfaatkan dan hanya menjadi limbah yang mencemari lingkungan. 


\section{KESIMPULAN DAN SARAN}

\section{Kesimpulan}

Berdasarkan kegiatan yang telah dilakukan oleh tim pelaksana, hasil yang telah diperoleh dari kegiatan ini dapat ditarik kesimpulan bahwa melalui kegiatan ini masayarakat dapat memperoleh tambahan pengetahuan dan keterampilan tentang bagaimana mengatasi permasalahan-permasalahan yang dihadapi oleh mitra yaitu dengan mengolah kotoran ternak ruminansia. Dengan adanya kegiatan pelatihan ini mitra dapat mengolah kotoran ternak ruminansia menjadi briket yang dapat menggantikan bahan bakar untuk memasak sehari-hari.

\section{Saran}

Adapun saran yang dapat diberikan berdasarkan hasil kegiatan pengabdian ini yaitu perlu adanya pengembangan lebih lanjut terkait proses produksi briket kotoran ternak ruminansia agar mitra dapat memproduksi dan memasarkan briket kotoran ternak ruminansia secara mandiri dan berkesinambungan dengan target pemasaran yang lebih luas. Selain itu, perlu juga dilakukan pelatihan pembuatan pengemasan terhadap hasil briket.

\section{DAFTAR PUSTAKA}

[1] Putri et al. 2014. Pengaruh jenis kotoran ternak terhadap kuantitas biogas. Jurnal Kesehatan Lingkungan. 4(1): 45-49.

[2] Santoso et al. 2010. Studi Variasi Komposisi Bahan Penyusun Briket dari Kotoran Sapi dan Limbah Pertanian. Universitas Andalas. Padang.

[3] Kasworo et al. 2013. Daur ulang kotoran ternak sebagai upaya mendukung peternakan sapi potong yang berkelanjutan di desa Jogonayan kecamatan Ngablak kabupaten Magelang. Prosiding Seminar Nasional Pengelolaan Sumberdaya Alam dan Lingkungan. ISBN 978-602-17001-1-2.

[4] Sarjono dan Ridlo M. 2013. Studi Eksperimental Penggunaan Kotoran Sapi Sebagai Bahan Bakar Alternatif. Majalah Ilmiah STTR Cepu Nomor 16, Tahun 11, Januari-Juni 2013.

[5] Pancapalaga dan Wihandako. 2008. Evaluasi Kotoran Sapi dan Limbah Pertanian (Kosap Plus) Sebagai Bahan Bakar Alternatif. 